\title{
Raised bed planting through broad bed furrow
}

\author{
Smita N. Solanki, S.H. Thakare and R.T. Ramteke
}

See end of the Paper for authors' affiliation

Correspondence to :

Smita N. Solanki

Department of Farm Power and Machinery, College of

Agricultural Engineering and Technology, Dr. P.D.K.V.,

Akola (M.S.) India

Email :smitansolanki@ yahoo.com
- ABSTRACT : In recent years, it is imperative to improve sowing techniques through preferred seedbed preparation and early crop growth. Sowing techniques and type of seeding machines play an important role in seed placement and seedling emergence which ultimately affect crop growth and grain yield. The selection of suitable planting methods is dependent upon the time of planting, irrigation methods, amount of residue in the field and type of planting machines. The present work deals with the review of research work done by using broad bed furrow (BBF) worldwide to study the effect of raised bed planting on soil health, yield, water saving, fertility of soil etc. From the study it is revealed that raised bed (RB) farming systems combine most of the elements of conservation agriculture and have produced encouraging production results under various environmental conditions. RBs offer the opportunity of reducing field compaction and restoring physically degraded soil structure, as well as, the potential to reduce irrigation water and increase crop yield while reducing the risk of water logging. Different raised planting configurations are used throughout the world depending on soil type, available machinery, farmer preference and expertise. In general, increasing the width of the bed reduces total water used and increases land use efficiency and yield by reducing the uncropped furrow area.

- KEY WORDS : Broad bed furrow, Permanent raised beds, Crop growth, Seedbed, Yield

-HOW TO CITE THIS PAPER : Solanki, Smita N., Thakare, S.H. and Ramteke, R.T. (2018). Raised bed planting through broad bed furrow . Internat. J. Agric. Engg., 11(2) : 400-408, DOI: 10.15740/ HAS/IJAE/11.2/400-408. Copyright@2018: Hind Agri-Horticultural Society. 